\title{
Diamond Model and Competition of Rubber Export Markets: Evidence from Sumatra Economic Growth Center
}

\author{
Ansofino Ansonfino, Zusmelia Zusmelia, Lovelly Dwinda Dahen, Yossi Eka Puteri
}

Economic Department, STKIP PGRI West Sumatra, Indonesia

\begin{abstract}
The focus of this research is on how the position of competitiveness of Indonesian rubber exports among ASEAN countries and the dominant factors causing the competitiveness of Indonesian rubber exports experienced a downward. Approach to measuring rubber export competitiveness uses the Lafay Index, and factors that affect the competitiveness using the Diamond model by using panel data analysis method. The results show that there has been a decline in the competitiveness of Indonesia's rubber exports to ASEAN countries, the greatest decline in competitiveness that occurred in Singapore, Malaysia, and Thailand. Factors that affect Indonesia's export competitiveness that is more dominant are a foreign direct investment, price levels, and interest rates. FDI should be directed at improving the quality of export products following the quality of ISNR and upgrading the quality of rubber export products from SIT 20, and directly more beneficial for the manufacture of goods for final consumers.
\end{abstract}

JEL Classification: F14, O24, P33, Q17

\section{Keywords}

Export competitiveness, the Lafay index, diamond model.

Ansonfino, A., Zusmelia, Z., Dahen, L. D. and Puteri, Y. E. (2021) "Diamond Model and Competition of Rubber Export Markets: Evidence from Sumatra Economic Growth Center", AGRIS on-line Papers in Economics and Informatics, Vol. 13, No. 1, pp. 15-27. ISSN 1804-1930. DOI 10.7160/aol.2021.130102.

\section{Introduction}

Export competitiveness is one of the determining factors in the persistence of a country's long-term economic growth, especially the tendency in manufacturing exports, besides the degree of equality of income distribution, democratically managed institutions, trade openness, and foreign direct investment. (Porter, 1981; Grant, 1991; Snowdon and Stonehouse, 2006; Berg et al., 2012). Openness Foreign trade which is believed by economists as a very effective factor in maintaining long-term growth should rely on trade in agricultural products that have been processed and have led to agroindustry and agribusiness, so that they have higher added value. (Burianová and Belová, 2012; Shoufeng, et al., 2011). Trade-in agricultural products which are superior products such as rubber by the center of economic growth is a mainstay product that is expected to drive economic growth in the central region of economic growth in Sumatra. (Ansofino, 2016; Jambor et al., 2017, Ansofino and Zusmelia, 2017; Svatos, et al., 2018; Huo et al., 2019; Ansofino et al., 2019).
Calculation of the competitiveness of a country's exports so far has mainly focused on the index revealed comparative advantage (RCA), taking into account the export value of products exported with and the total export value of all commodities produced by a country. (Balasa and Noland, 1989; Ansofino and Zusmelia, 2018; Jambor et al., 2017). This RCA Index has been able to provide the position of export competitiveness of countries among other parts of the world (Vollrath, 1991; Sarker and Ratnasena, 2014; Bojnec and Ferto, 2014), such as the export competitiveness of agricultural products in Africa, Canada, and Europe. The use of the RCA index has even been combined with trade competitiveness indexes that are more specific to trade products such as coffee, rubber, and cocoa (Shoufeng, Feng and Jiao, 2011).

The concept of competitiveness has been used extensively, especially at the country, company, industry, and trade product levels (Bhawsar, 2015; Boonpattarakan, 2012; Qin and Pastory, 2012; Svatos et al., 2018; Zhang et al., 2010; Xue Liu, 
2009). This study analyzes the competitiveness of the Indonesian state using product data Indonesia's rubber exports to ASEAN, and other countries. The study of competitiveness at the country level has been established in the monumental work of Porter 1990; Porter, 1981; Grant, 1991), by making data on exports and imports of major commodities as material for analysis. Trade competitiveness in the form of rubber exports uses the revealed comparative advantage index and uses a diamond model framework from Michael Porter with several modifications (Kamath et al., 2012), so that the diamond model from Michael Porter has rearranged the theory of regional and national competitiveness to the theory of locative competitiveness advantage (Kamath et al., 2012). There are four determinants of regional and national location competitiveness namely local demand conditions, factor condition, the presence of similar industrial competitors, and finally the company strategy that refers to the rules and incentives and norms that apply in the competition at the local level.

Determination of regional economic competitiveness, especially in producing cluster development, in this case, is the emergence of emerging markets, namely the economic corridor of Sumatra, of course also influenced by several determining factors for its success (locational success), namely demand conditions, factor conditions, democratic institutional support, knowledge spillover, technology transfer, economic agglomeration, increasing returns, public policy and the presence of social infrastructure and capital and the most important is the presence of creative groups (Kamath et al., 2012; Florida, 2012, Romer, 1990; Almeida and Kogut, 1999; Combes, et al, 2005; Billings and Johnson, 2016; Joas, 1996), all of which have become attributes of economic clusters or economic corridors and economic growth to be able to compete directed by this diamond factor.

The competitiveness of agricultural exports such as rubber has been traditional support for emerging markets in regional and global competition, the diamond model can provide an important basic framework in analyzing the competitiveness of rubber exports at the center of economic growth (emerging markets) of Sumatra and the ASEAN region in general. The interconnectedness of rubber economic resources in the Sumatra economic corridor can offer Indonesia's competitive advantage in the face of trade competition with ASEAN countries. The spatial effect of interconnecting rubber economic resources on the regional competition market can be analyzed with the Diamond model (Porter, 1981; Grant, 1991) with its development on the Lafay Index, (Huo, et al, 2019; Kamath et al., 2012). The main problem examined in this study is whether the rubber trade center of the Sumatra corridor has competitiveness in trade with the ASEAN region and globally? What factors influenced the increase in the competitiveness of rubber exports in the Sumatra economic corridor? how to increase the added value of the rubber economy and be able to capture its economic rent by rubber entrepreneurs in their hinterland areas?

\section{Materials and methods}

The measurement of rubber export competitiveness from the export growth centers of Sumatra's economic corridors uses the revealed comparative advantages (RCA) method (Balasa and Noland, 1989; Kamath et al., 2012; Qineti et al., 2009), and the Lafay Index (Svatos et al., 2018; Burianová and Belová, 2012; Zaghini, 2003), while the factors affecting power Sumatra's economic corridor rubber export competitiveness refers to the Diamond model pioneered by Porter (1990), and Grant (1991) and developed into the global economics management system (GEMS) by Kamath et al. (2012).

The RCA model used to calculate the competitiveness of rubber exports in the Sumatra economic corridor takes the following form:

$$
R C A_{j}=\left(\frac{X_{j}-M_{j}}{x_{j}+M_{j}}\right) 100
$$

where $X_{j}$ and $M_{j}$ are the value of exports and imports of agricultural products including rubber in the economic corridor area of Sumatra. To maintain the stability of the RCA index value, Balassa (1977) recommends using the RCA index in the form of a ratio too, namely:

$$
R C A 1_{j}=\left(\frac{X_{j} / M_{j}}{X_{M}}\right) \text {, }
$$

where $X_{j}$ and $M_{j}$ are agricultural export values including rubber from the Sumatra economic corridor area, while $X$ and $M$ are the total export and import values of the agricultural sector trade in the Sumatra Economic Corridor region. Both of these models assess, if the RCA index is greater than one, then the rubber commodity analyzed is competitive, and vice versa, rubber commodity 
with an RCA index of less than one becomes less competitive.

The limitations of the RCA index model are more likely to be appropriate for analyzing the competitiveness of exports in a country's trade with its partners, but must also consider global trade conditions or the global macroeconomic situation, so for this purpose, this study also uses the Lafay Index (Lafay, 1992; Dagenais and Muet, 1992) which takes the following form:

Lapay Index (LFI) =

$=\left(\frac{X_{j}^{i}-M_{j}^{i}}{X_{j}^{i}+M_{j}^{i}}-\frac{\sum_{j=1}^{N}\left(X_{j}^{i}-M_{j}^{i}\right)}{\sum_{j=1}^{N} X_{j}^{i}+M_{j}^{i}}\right) \frac{X_{j}^{i}+M_{j}^{i}}{\sum_{j=1}^{N} X_{j}^{i}+M_{j}^{i}} 100$

Where $X_{i j}$ and $M_{i j}$ represent exports and imports of rubber products represented by country $i$ up to the number of $N$ countries. The LFI index consists of three elements namely:

$$
\begin{aligned}
& L F I_{1}=\frac{X_{j}^{i}-M_{j}^{i}}{X_{j}^{i}+M_{j}^{i}} \\
& L F I_{2}=\frac{\sum_{j=1}^{N}\left(X_{j}^{i}-M_{j}^{i}\right)}{\sum_{j=1}^{N}\left(X_{j}^{i}+M_{j}^{i}\right)} \\
& L F I_{3}=\frac{X_{j}^{i}+M_{j}^{i}}{\sum_{j=1}^{N}\left(X_{j}^{i}+M_{j}^{i}\right)}
\end{aligned}
$$

So that $L F I=\left(L F I_{1}-L F I_{2}\right) L F I_{3} x 100$

$L F I_{1}$ measures net exports for certain commodities such as rubber with all exports in the agricultural sector, this is commonly measured in the Balassa RCA index model. $L F I$, compares the total net exports (the sum of all commodities) with the total trade in the agricultural sector, the value of LFI will be positive if $L F I_{1}>L F I_{2}$, this is the RCA index of certain trade commodities with the sum of all traded commodities. $\mathrm{LFI}_{3}$ is the share of a certain commodity against all the total trade of a country. The positive value of the LFI index indicates the existence of export competitiveness, whereas the negative value of the LFI index reflects the lack of competitiveness of export competitiveness.

Factors that affect the competitiveness of rubber exports in the corridor region of Sumatra refer to the diamond model in which five variables affect the competitiveness of these exports, namely: demand condition in the region (demand condition). According to Porter (1990) demand condition is measured by identifying (1) the size and composition of local demand, (2) the size and growth of local demand, (3) the number of local traders (local buyers) (Kamath et al., 2012). This study measures the demand condition of the growth of rubber imports and the number of rubber traders (local buyers), so that the growth of imports will reduce the competitiveness of imports, as well as the increasing number of rubber traders will make rubber competitiveness weaker, because most rubber traders have not made an increased value-added (processing) in trade (Ansofino, 2016; Ansofino and Zusmelia, 2018; Ansofino, et al., 2019; Ansofino, and Zusmelia, 2019). The data used was obtained from the world integrated trade solution (https://wits.worldbank. $\operatorname{org} /$ ).

Factor conditions in the form of supply, production costs, labor productivity, technology, management, entrepreneur. This study uses data on the amount of rubber production produced by each country, and the amount of innovation and entrepreneurship produced by each country. Data were obtained from the Asian Development Bank (https://data.adb.org/dataset/basic-statisticsasia-and-pacific).

Factors in the presence of supporting industries such as industry partners, availability of logistics services, accounting, and legal services, financial and tax services, distribution services, and export services, including in this case innovation and use of technology (technological cluster), the creation of agglomeration of the rubber processing industry.

Factor firm, strategy, structure, and competitors (rivalry) as a form of ability and climate of local competitiveness, a macroeconomic climate, and a conducive political climate, a culture of innovation and local entrepreneurs. Factors that shape local competitiveness are also policies related to trade and investment openness, licensing rules, antitrust policies, the influence of corruption, (Kamath, et al., 2012), (Porter, 1981). It is expected that all of these variables can explain the level of competitiveness of Indonesia's rubber trade in ASEAN countries.

\section{Results and discussion}

\section{Competitiveness of Indonesia's rubber exports with ASEAN countries}

Indonesia's rubber exports to ASEAN countries as its main trading partners have continued to increase since three decades ago, especially since the boom in oil exports in the 1980s was replaced by a boom in crop exports in the 1990s until the end of 2011, the increase in exports was allegedly by increasing the amount oil palm and rubber smallholder farms (Euler et al., 2016; 
Winoto and Siregar, 2008). Rubber and palm oil are trade commodities that are the mainstay of the economy of the Sumatra economic corridor. However, the added value of the rubber trade is still captured by the trade partners of ASEAN countries, specifically Singapore and Malaysia. (Ansofino and Zusmelia, 2018).

Figure 1 illustrates the increasing trend of Indonesia's rubber exports to ASEAN countries. There are at least three shocks that have decreased, namely the economic crisis events in 1998. The greater shocks that occurred in 2009 were more due to natural disasters; an earthquake in West Sumatra province as a center for rubber production in Indonesia. The recovery in the post-disaster rubber export increase reached its peak in 2011, and is slowly continuing to slowdown until now.
The main export destination countries for Indonesia's rubber and volume are Malaysia, Vietnam, Thailand, and Singapore. However, the State of Singapore has received the greatest increase in added value (Ansofino, et al, 2018), the trend has continued to decline over the past two decades. Even so, the percentage of rubber exports to ASEAN countries, when compared with total exports to the relevant countries, the trend continues to increase, especially to Vietnam, the Philippines, and Malaysia (see Figure 2). Two countries namely Singapore and Malaysia showed a share of rubber exports with a decrease in total exports.

Indications of the declining trend in the share of rubber exports to Singapore, and Thailand, reinforced by the decline in export competitiveness as indicated by its Lafay index figures which

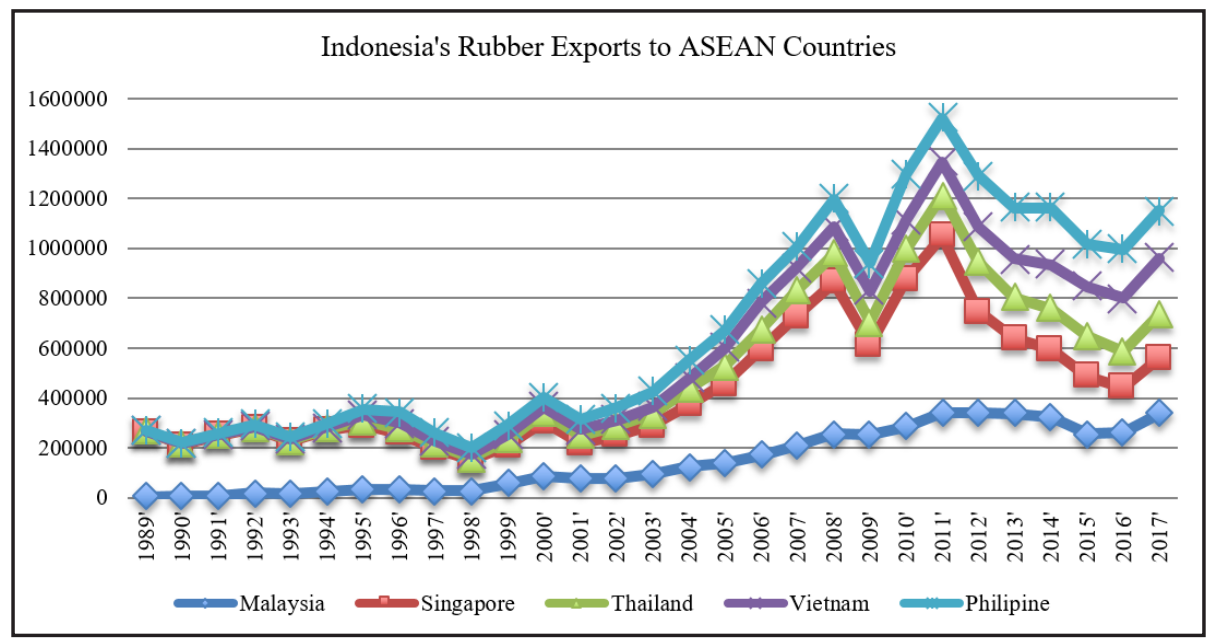

Source: Own calculation based on data from the Wits World Bank, 2019

Figure 1: Development of Indonesia's rubber exports to ASEAN countries.

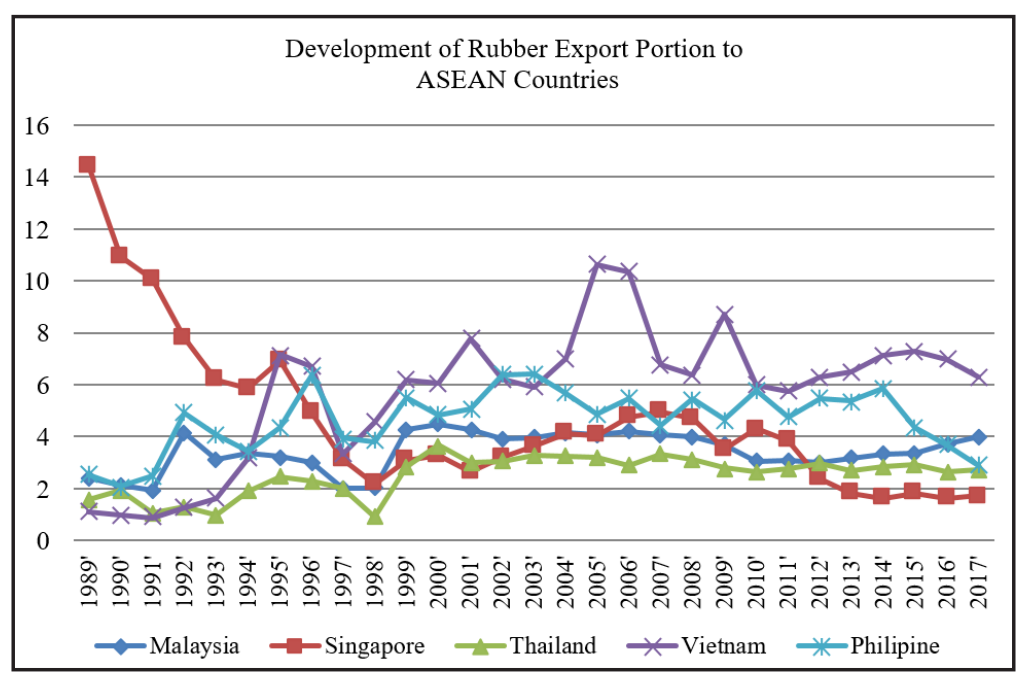

Source: Own calculation based on data from Wits World Bank, 2019

Figure 2: Development of rubber export portion to ASEAN countries. 
have also declined since the economic crisis period in 1998 and experienced increasingly less competitive, in line with the increasing competitiveness of exports to Vietnam and the Philippines. Nonetheless, the total trade activities between Indonesia and ASEAN countries as indicated by the value of trade turnover, the trend is still increasing since the last two decades and is still dominated since the beginning with the countries of Singapore, Malaysia, and Thailand.

The increasing trend of Indonesia's trade activities with ASEAN countries is shown by the increasing value of turnover and is led by Singapore, Malaysia, and Thailand, (see Figure 3) but in these three countries, the Lafay Index value which measures the competitiveness of Indonesia's rubber exports experiences decrease (see Figure 4). The sharpest decline in the competitiveness of Indonesia's rubber exports was in Singapore, and Malaysia, and Thailand. However, in line with the declining competitiveness of Indonesia's rubber exports, the three ASEAN countries which have been the main trade partners, have been followed by the expansion, and increase of Indonesia's trade activities with the Philippines and Vietnam.

This indicates that the export of Indonesian rubber in the form of raw rubber (crumb rubber), which has not been done to increase the added value in the form of processed rubber products that have high added value, but the processing of raw rubber to the next stage of rubber industry products that provide higher added value has been carried out by Singapore, Malaysia, and Thailand. This is in line with the findings of Ansofino, et al. (2018) and (Ansofino and Zusmelia, 2018) which states that the added value of Indonesia's rubber trade is captured by Singapore countries, Malaysia and Thailand. That is why, the trend of Indonesia's rubber trade to these three countries remains high

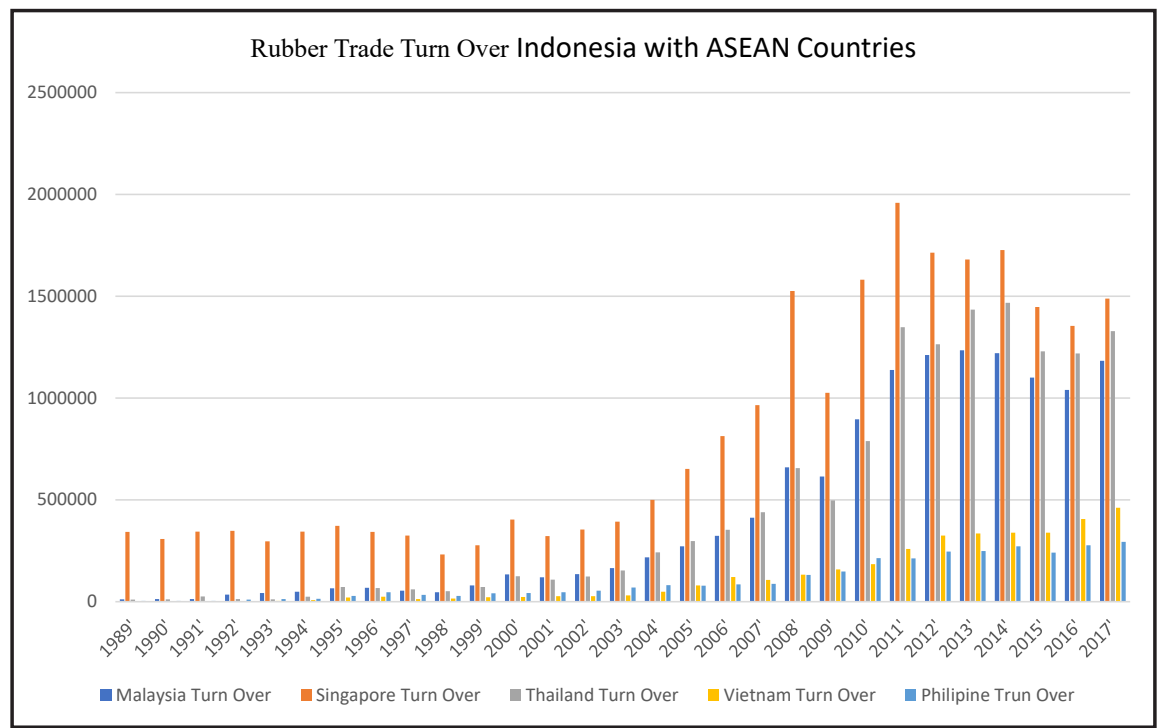

Source: Own calculation based on data from the Wits World Bank, 2019

Figure 3: Comparison of the intensity of Indonesia's rubber trade with ASEAN countries.

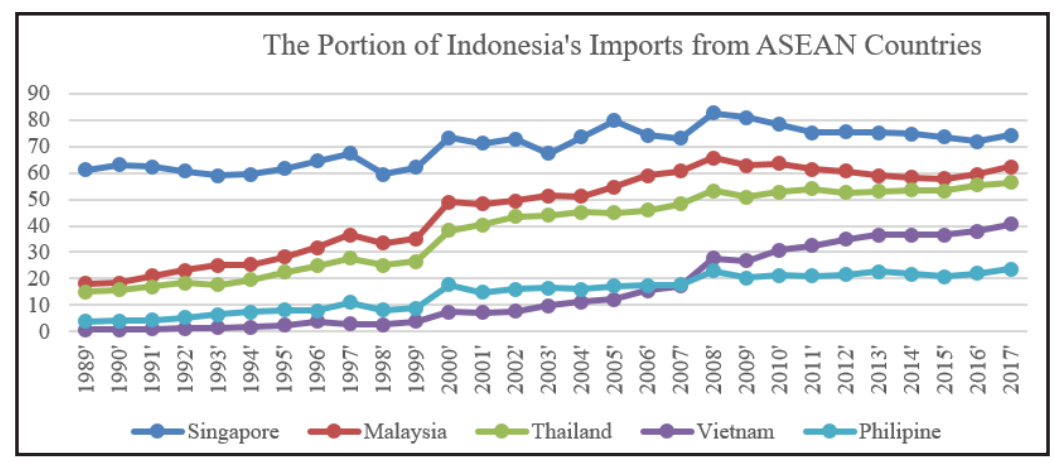

Source: Own calculation based on data from the Asian Development Bank, 2019

Figure 4: Percentage of Indonesia's imports from five ASEAN countries. 
because these countries do need a supply of raw rubber from Indonesia to be processed into other rubber industry products that provide high added value, such as swimsuits, automotive industry requirements and others so.

The intensity of Indonesia's rubber trade with the ASEAN countries being the most continuous is with Singapore, Malaysia, and Thailand, the net value of rubber exports to these three countries has continued to decline, but since the economic crisis and global financial crisis, the orientation of Indonesia's rubber exports in the form of raw rubber began widened to Vietnam and the Philippines so that it can be said that the net value of Indonesia's rubber exports increased in Vietnam and the Philippines. This means that Indonesia's high net rubber exports to the Philippines and Vietnam are due to smaller Indonesian imports from the latter country.

Indonesia's imports from the largest ASEAN countries are from Singapore, Malaysia, and Thailand compared to Indonesia's imports from Vietnam, and the Philippines which are much smaller as shown in Figure 4. Indonesian imported goods from Singapore that made Indonesia's competitiveness lower were mainly consumer goods, fuel, intermediate goods, capital goods and machinery, chemicals, and then plastic and rubber goods. All of these imports are processing materials for the processing industry in Indonesia, so of course the economic value is far higher than the economic value of rubber exports to Singapore in the form of raw rubber. The types of goods are similar to Malaysia, where the biggest types of goods imported from Malaysia are fuel, consumer goods, intermediate goods, capital goods, and machinery and electronics, even including plastic, and rubber. This means that the intensity of trade between Indonesia, and the two biggest countries, whose trade with Indonesia so far, has turned out to be more focused on consumer goods and capital goods and even intermediated goods. Even when viewed from Singapore and Malaysia's imports from Indonesia, it is not rubber and rubber products which are the most dominant, even food products and vegetables which are Indonesia's leading commodities and even the economic corridors of the Sumatra region, including the types of imported goods which are not the top priority in Singapore's import composition, and This Malaysia. So it can be said that if you want to increase Indonesia's competitiveness of these two countries, the intensity of Indonesia's trade, especially exports, must be from consumer goods, intermediated goods, fuel goods, capital goods, not raw materials, especially food products whose portions are very small imported. by Singapore and Malaysia from Indonesia.

Figure 4 above shows that Indonesia's imports in ASEAN countries with the type of fuel products, consumer goods, intermediated goods, and capital goods are dominated by 3 countries namely Singapore, Malaysia, and Thailand. After that followed by Vietnam and the Philippines. These five countries are Indonesia's biggest trade partners among other ASEAN countries. However, compared to Indonesia's exports to these countries, the value is much smaller. That is why Indonesia's trade balance with the three ASEAN countries has always been negative. Therefore, Indonesia's leading commodity, specifically economic corridors in the form of crumb rubber, must be of low competitiveness.

Measurement of the competitiveness of Indonesia's rubber exports to ASEAN countries using the Lafay Index as seen in the results in Figure 5 shows that the competitiveness of Indonesia's rubber exports to Singapore, Malaysia, and Thailand has declined over the past two decades. The drastic decline in the competitiveness of rubber exports was also evident from the low ranking order of Singapore's state imports from Indonesia, the type of rubber commodity occupying the fifth-lowest position for the large portion of Singapore's imported goods types from Indonesia, while Vietnam ranked eighth. The top order for the portion of imported goods from Indonesia in the countries of Singapore and Vietnam remains in the form of consumer goods, intermediated goods, capital goods. Because of the composition of Vietnam's imports place raw materials in the top third, so the turn over of Indonesia's rubber exports to Vietnam is getting bigger.

The competitiveness of Indonesia's rubber exports to Malaysia is better than that of Singapore (see the Figure 5). The types of goods exported to Malaysia, plastic goods, and rubber ranks at the top eight, while the same goods to Singapore rank at the bottom five imported by Singapore from Indonesia. So that the competitiveness of Indonesia's rubber exports to Malaysia is far greater than that of Singapore. So it can be said if the type of Indonesian export goods is still at the level of raw materials, and rubber raw materials, then its competitiveness will be low with countries that have been processing and increasing added value, which can be seen 


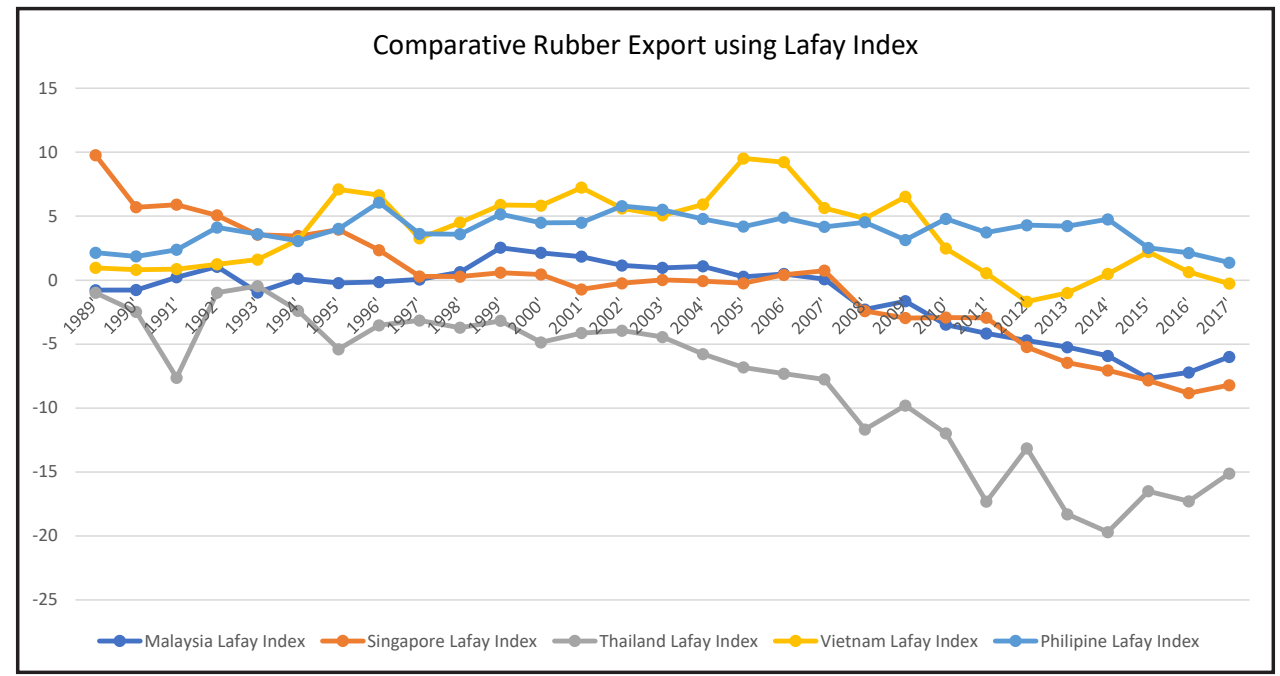

Source: Own calculation based on data from the Asian Development Bank, 2019

Figure 5: Competitiveness rubber export using Lafay index.

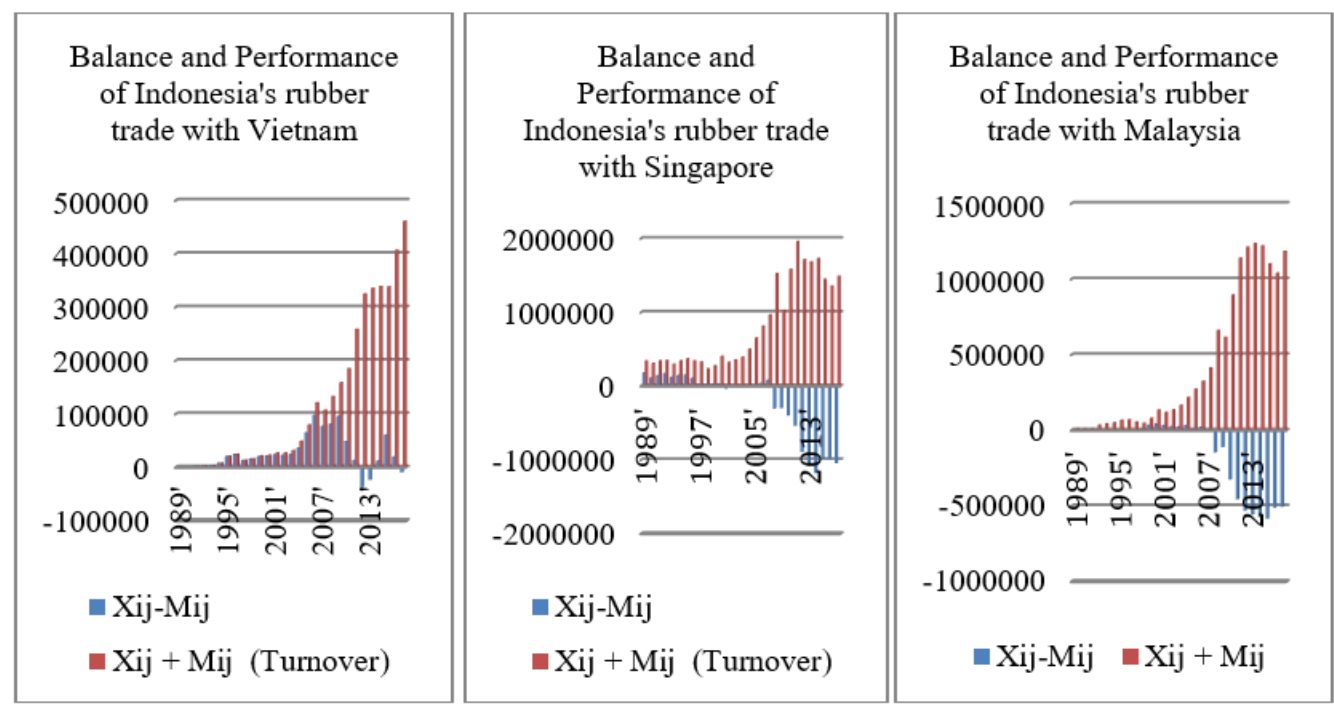

Source: Own calculation based on data from the Asian Development Bank, 2019

Figure 6: Comparison of Indonesia's rubber trade intensity with Vietnam,

Singapore and Malaysia.

from the composition of imported goods that place raw goods and agricultural foods as lowest order in importing to his country. Conversely, if the types of Indonesian exported goods are at the level of intermediated goods, consumer goods, and capital goods, then the intensity of Indonesia's trade with ASEAN countries will be dominated by Singapore, Malaysia, and Thailand. The presence of Vietnam, and the Philippines which strengthen Indonesia's competitiveness is more because these two countries still place raw material as the type of goods that ranks in the top five, including rubber.

The Figure 6 above shows that the performance of Indonesia's rubber exports to Vietnam is still experiencing an increase which is shown by its turnover value, but the value of net exports in Singapore and Malaysia has decreased since the period of the global financial crisis hit Indonesia's trade. Therefore, in improving Indonesia's trade performance, especially in the type of rubber commodity, it is necessary to find partner countries that still need raw materials in their imports, such as Vietnam, and the Philippines. A more elegant way to increase trade intensity with ASEAN countries is of course by taking a position on consumer goods, intermediated goods, and capital goods began to avoid types of food goods and goods with other lower value-added products. 


\section{Diamond model of Indonesia's rubber export competitiveness}

The competitiveness of Indonesia's rubber exports with ASEAN countries which has been calculated using the Lafay Index shows that the competitiveness of Indonesia's rubber exports to Singapore, Malaysia, and Thailand has declined, so far it has been a destination for Indonesian rubber exports. In line with that, the competitiveness of Indonesia's rubber exports has increased with Vietnam and the Philippines. Several factors that affect the competitiveness of rubber exports have been specified by referring to the Diamond model.

Three types of panel data were tested by pooled least square (PLS), fixed effect method (FEM), and random effect method (REM) testing methods. The assumption used for the fixed effect method is the diversity of the competitiveness of Indonesia's rubber exports with the unobserved ASEAN major partners correlated with several unobserved characteristics. While the assumption for the RE method is that the diversity of Indonesia's export competitiveness characteristics that are not observed is uncorrelated with the observed characteristics. Determination of whether the panel data testing model for rubber export competitiveness is in Pooled, FE, or RE, then the Chow-likelihood ratio test, and Hausman Test are used (Bai, 2013).

The results of the diamond model testing which showed the most appropriate model to analyze are the fixed effect model shown by a significant Chow-likelihood ratio value so that the diversity of Indonesia's rubber export competitiveness with the unobserved ASEAN countries correlates with several observed characteristics (Table 1).

\begin{tabular}{|l|c|c|}
\hline & Pooled Method & Fixed Effect Model \\
\hline Constanta & -43.16 & $-19.8157^{* *}$ \\
FDI & $5.77(1.40)$ & $-2.97(-0.845)$ \\
Price Competition & $2.06(5.33)^{* *}$ & $8.86(1.77)^{*}$ \\
Exchange rate & $0.1039(3.10)^{* *}$ & $0.0666(2.036)^{*}$ \\
Rubber export & $-0.000692(-1.08)$ & $0.000740(0.47)$ \\
Interest rate & $2.23(3.46)^{* *}$ & $3.74(0.89)$ \\
Import & $2.631(5.08)^{* *}$ & $-0.7048(-1.858)^{*}$ \\
R2 & $8.69(1.02)$ & $1.62(1.95)^{*}$ \\
F Statistic & 0.805379 & 0.984398 \\
Sample Periode & 18.91747 & 73.612 \\
Number Observation & $2010-2017$ & $2010-2017$ \\
\hline
\end{tabular}

Note: $*$ significant $10 \%$, ** significant level 5\%

Source: Own calculation based on data from the Wits World Bank, 2019

Table 1: Estimation panel of export competitiveness and its components.
After testing the model with the Chow Likelihood Ratio Test, the assumption of Indonesia's export competitiveness is a fixed-effect model for the cross-section, and its period can finally be accepted, because the chi-square cross-section value is 57,31 and the value of the cross-section chi-square period is 100,94 , this is significant for all levels of statistical testing.

Indonesia's export competitiveness is significantly affected by foreign direct investment (FDI), price competitiveness, rubber export value, and interest rates, whereas consumers good, exchange rate and import values do not significantly and significantly influence the export competitiveness of countries ASEAN, as indicated by the regression results table using the pooled method above. Changes in FDI Indonesia's price competitiveness will have an impact on increasing Indonesia's export competitiveness of US \$2.06 billion and the US \$ 0.1039 billion, respectively. The larger change to increase Indonesia's export competitiveness was contributed by an increase in rubber exports and interest rates of US \$ 2.23 billion and the US $\$ 2.6$ billion, respectively.

The decline in export competitiveness can be seen from the negative constant value of -43.16 in the pooled data method, and by -19.8157 in the fixed-effect model. Three countries that have been Indonesia's rubber trade partners, Singapore, Malaysia, and Thailand, have experienced the greatest impact on the decline in Indonesia's rubber export competitiveness in ASEAN countries. This is in line with the third Lafay Index, which is lower than Vietnam, and the Philippines as the more intense rubber trading partner in the last five years. From internal factors alone, the cause of the low competitiveness of Indonesian rubber is in addition to the composition of imports of these three countries which emphasizes on processed products or consumer goods is the quality of Indonesian rubber export products which are still in the form of raw rubber, it is necessary to increase the quality of products to increase added value, (Svatos, Smutka and Miffek, 2018), so with the countries of Vietnam and the Philippines, the portion of rubber products produced by Indonesia becomes the composition of its imports, which ranks fifth of all imported products.

Indonesia's export competitiveness turned out to be a downward trend from the period of 2010 to 2017 export destination countries which contributed the most to the decline in competitiveness were Thailand, Singapore, and Malaysia, compared to Vietnam and the Philippines, as seen in the Figure 7. The highest period of decline 


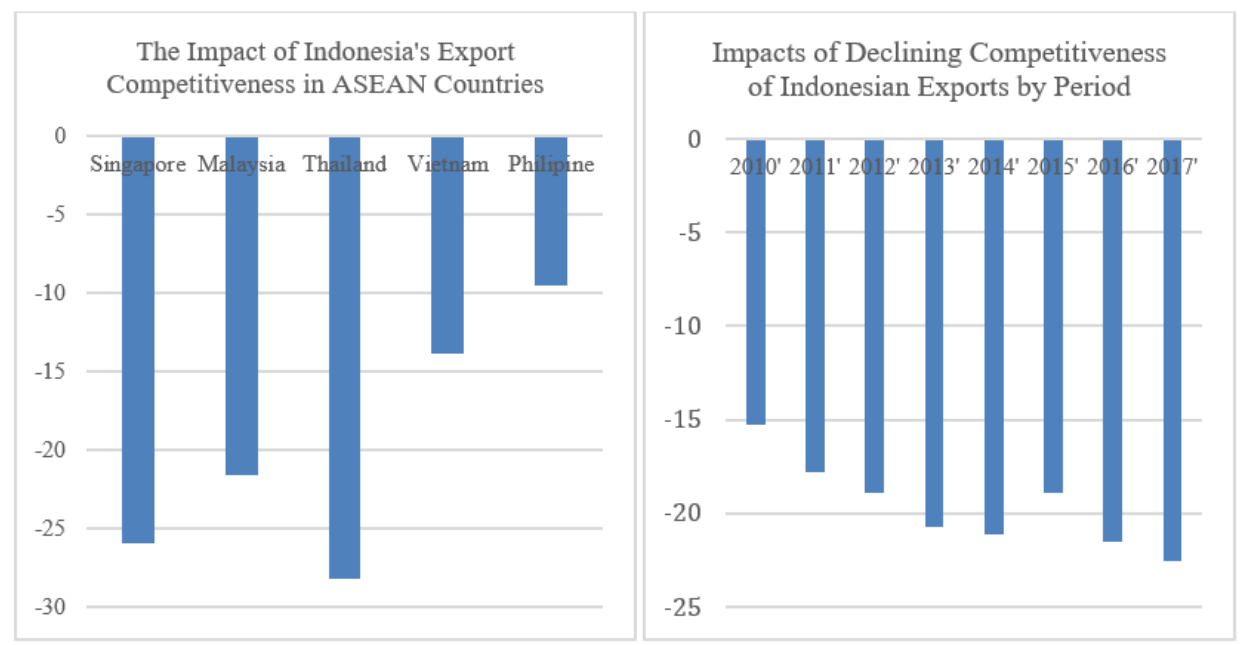

Source: Own calculation based on Fixed Effect Model, 2019

Figure 7: Impact of the declining competitiveness of Indonesia's exports to ASEAN trade partner countries, and their periods.

in export competitiveness occurred in 2017 , although competitiveness had strengthened in 2010 and 2015.

The deciding factor for the decline in Indonesia's export competitiveness is the FDI factor, this is in line with the findings of Huo (2019) and (Huo et al., 2019), that the impact of FDI, and the price level on export competitiveness especially agricultural products is positive in emerging market countries, including Indonesia. The interest rate, and the size of rubber exports were able to increase Indonesia's export competitiveness, but this rubber export was no longer significant in the fixedeffect model. FDI, which is believed to be able to have an impact on creating improved technology for processing rubber products, and increasingly efficient management of rubber export companies, (Zhang et al., 2010) turns out that such an impact has not yet occurred in the rubber industry in Indonesia. Specifically in West Sumatra there are 8 rubber exporting companies and all of their products are SIR 10, 20 (http://www.gapkindo. org/id/cabang/101-west-sumatera).

Unlike Singapore, Malaysia, and Thailand, their rubber export products are ribbed smoked sheets (RSS 3) which are directly used as raw materials for making aero tires, tubes, footwear, handmade hoses. Singapore needs more technically specific rubber (TSR 20) products for manufacturing medical equipment, engineering, automobile, footwear, condoms, industrial glove, and so on. Noting differences in the quality of rubber products traded in Indonesia in the form of sheets of Indonesian rubber (SIT 10, 20) which are still far from the quality of standard Indian natural rubber (ISNR) (https://www.thomsonrubbers. com/natural_rubber.html). So that it can be said that the declining competitiveness of Indonesian rubber exports which is highly determined by FDI, and the level of rubber prices, is evident in the empirical fact that companies engaged in rubber exporters in Indonesia have not processed rubber products that are in the ISNR standard which so far have set 2 types of sheets rubber produced, and marketed in the International trade market, namely: ribbed smoked sheet (RSS), and air-dried sheets (ADS).

In line with the price differences caused by differences in quality among ASEAN rubber producing countries, which has made Indonesia's rubber product export competitiveness decline, it turns out that Indonesia's SIR 20 prices are far lower than the types of RSS, TSR, and SMR produced by Thailand, Singapore, and Malaysia. In January 2020 the maximum price of TSR Singapore reached 174.30 US cent $/ \mathrm{kg}$, RSS 3 Thailand the maximum price reached the US 166.01 cents $/ \mathrm{kg}$, while the maximum price of SIR 20 GAPKINDO Indonesia at the same time only reached 154.60 US \$ cents $/ \mathrm{kg}$ (see ASEAN rubber price statistics: http://aseanrubber.net/ arbc/index.php/january-2020-side). Therefore, to increase the price of Indonesian rubber export products, it must meet 2 types of ISNR which become the world rubber trade standard. FDI activities in the rubber industry should focus on this locus. 


\section{Conclusion}

Based on the main issues, and discussions that have been carried out, conclusions can be drawn from the results and discussions that have been carried out using various analytical tools.

The volume of Indonesia's rubber exports to ASEAN countries has been increasing for the past three decades. The biggest increase in export values, which at present are Vietnam, and the Philippines, in addition to Singapore, Malaysia, and Thailand. There has been a shift in the orientation of Indonesia's rubber exports from the original to Singapore, Malaysia, and Thailand, slowly moving to Vietnam, and the Philippines over the past decade.

There has been a decline in the competitiveness of Indonesia's rubber exports to ASEAN countries, the greatest decline in competitiveness that occurred in Singapore, Malaysia, and Thailand.
The factor causing the decline in competitiveness is due to the quality of Indonesian rubber products which are still at the level of raw rubber, which no longer ranks highest in the composition of ASEAN countries' imports. The three countries mentioned have been processing rubber into consumer goods with higher added value.

The decline in competitiveness of Indonesia's rubber exports is evident from the decline in the Lafay index value, and the results of the fixed effect model (FEM) test. Factors that affect Indonesia's export competitiveness that is more dominant are foreign direct investment (FDI), price levels, and interest rates. FDI must be directed at improving the quality of export products following the quality of ISNR and upgrading the quality of rubber export products from SIT 20 slowly to switch to RSS and TSR which prices are higher and directly more beneficial for the manufacture of goods for final consumers.

Corresponding authors

Prof. Dr. Ansofino, M.Sc

Economic Department, STKIP PGRI West Sumatra

Gunung Pangilun Street, Number 1, Padang City, West Sumatra Province, Indonesia, P. C. 25144

Phone: +620751-7053731,E-mail: stkip_pgripadang@yahoo.co.id,ansofino@stkip-pgri-sumbar.ac.id

\section{References}

[1] Almeida, P. and Kogut, B. (1999) "Localization of knowledge and the mobility of engineers in regional networks," Management Science, Vol. 45, No. 7, pp. 905-917. ISSN 00251909. DOI 10.1287/mnsc.45.7.905.

[2] Ansofino, A. (2016a) "The Development of the West Sumatra Economic Corridor as a Strategy to Strengthen Connectivity with the Economic of ASEAN Countries", Economica Journal, Vol. 4, No. 2. ISSN 2302-1590.

[3] Ansofino, A. (2016b) “Integrasi perekonomian kabupaten dan kota di Sumatera Barat menuju integrasi pasar untuk menghadapi masyarakat ekonomi ASEAN 2015”, IPTEKS Terapan, Vol. 9, No. 2, pp. 137-154. ISSN 1979-9292.

[4] Ansofino, A. and Zusmelia, Z. (2018) “Comparative and Competitive Advantages Analysis of Rubber as A Featured Product of West Sumatra to Support of Spatial Interaction”, Proceeding International $\left(\right.$ ICEEE $\left.3^{\text {rd }}\right)$. ISBN 978-979-028-853-9.

[5] Ansofino, A. and Zusmelia, Z. (2017) "Towards Economic Linkages and Market Integration in Facing ASEAN Economic Community: Case Study West Sumatra Economy", International Journal of Economic Research, Vol. 14, No. 15, pp. 429-441. ISSN 0972-9380.

[6] Ansofino, A., Zusmelia, Z., Malinda,Y. and Dahen, L. D. (2018) "Regional Economic Improvement Model through Integration of West Sumateran Rubber Market with ASEAN Regional Market", Proceedings of the Social and Humaniora Research Symposium (SoRes 2018), Unisba Bandung. ISSN 2352-5398. DOI 10.2991/sores-18.2019.108.

[7] Ansofino, A., Zusmelia, Z., Malinda,Y. and Dahen, L., D. (2019) “The Spatial Integration of Crumb Rubber market within ASEAN Countries," Academic of Strategic Management Journal, Vol. 18, No. 4, pp. 1-13. ISSN 1544-1458, [Online]. Available: https://www.abacademies.org/articles/TheSpatial-Integration-of-Crumb-Rubber-Markets-within-ASEAN-Countries-1939-6104-18-4-406. pdf. [Accessed: 14 Feb., 2020]. 
[8] Bai, J. (2013) "Fixed-Effects Dynamic Panel Models, a Factor Analytical Method", Econometrica, Vol. 81, No. 1, pp. 285-314. ISSN 0012-9682. DOI 10.3982/ECTA9409.

[9] Balasa, B. and Noland, M. (1989) "Revealed Comparative Advantage in Japan and the United States", Journal of Economic Integration, Vol. 4, No. 2, pp. 8-22. ISSN 1015356X. DOI 10.11130/jei.1989.4.2.8

[10] Berg, A., Ostry, J. D. and Zettelmeyer, J. (2012) "What makes growth sustained?", Journal of Development Economics. International Monetary Fund, Vol. 98, No. 2, pp. 149-166. ISSN 03043878. DOI 10.1016/j.jdeveco.2011.08.002.

[11] Bhawsar, P. and Chattopadhyay, U. (2015) "Competitiveness: Review, Reflections and Directions", Global Business Review, Vol. 16, No. 4, pp. 665-679. ISSN 0972-1509. DOI 10.1177/0972150915581115.

[12] Billings, S. B. and Johnson, E. B. (2016) "Agglomeration within an urban area", Journal of Urban Economics, Vol. 91, pp. 13-25. ISSN 00941190, DOI 10.1016/j.jue.2015.11.002.

[13] Bojnec, Š. and Ferto, I. (2014) "Export competitiveness of dairy products on global markets: The case of the European Union countries", Journal of Dairy Science, Vol. 97, No. 10, pp. 6151-6163. ISSN 0022-0302. DOI 10.23986/afsci.9373.

[14] Boonpattarakan, A. (2012) "Competitive Capabilities of Thai Logistics Industry: Effects on Corporate Image and Performance", International Journal of Business and Management, Vol. 7, No. 5, pp. 19-30. E-ISSN 1833-8119, ISSN 1833-3850. DOI 10.5539/ijbm.v7n5p19.

[15] Burianová, J. and Belová, A. (2012) “The competitiveness of agricultural foreign trade commodities of the CR assessed by way of the Lafay Index", Agris On-line Papers in Economics and Informatics, Vol. 4 (SUPPL.SPL. 4), pp. 27-36. ISSN 18041930.

[16] Combes, P. P., Duranton, G. and Overman, H. G. (2005) "Agglomerasi and the adjustment of the spatial economy", Papers in Regional Science. Vol. 84, No. 3, pp. 311-349. E-ISSN 1757-7802. DOI 10.1111/j.1435-5957.2005.00038.x.

[17] Dagenais, M. G. and Muet, P. A. (1992) "International Trade Modelling", Edited by Homa MotamenScobie, London: Chapman \& Hall. ISBN 9781475721522.

[18] Euler, M., Schwarze, S., Siregar, H. and Qaim, M. (2016) “Oil Palm Expansion among Smallholder Farmers in Sumatra, Indonesia”, Journal of Agricultural Economics, Vol. 67, No. 3, pp. 658-676. ISSN 14779552. DOI 10.1111/1477-9552.12163.

[19] Florida, R. (2012) "The Rise of The Creative Class", Revisited, Philadelphia, USA: Basic Books, Philadelphia, USA. ISBN 9780465029938.

[20] Grant, R. M. (1991) "Porter's Competitive Advantage of Nations: An Assessment", Strategic management Journal, Vol. 12, pp. 535-548. ISSN 1098-6596. DOI 10.1002/smj.4250120706.

[21] Huo, D., Chen, Y., Hung, K., Song, Z. Guan, J. and Ji, A. (2019) "Diamond model and the export competitiveness of the agriculture industry from emerging markets: an exploratory vision based on a spatial effect study using a genetic algorithm”, Economic Research-Ekonomska Istrazivanja. DOI 10.1080/1331677X.2019.1679212.

[22] Jambor, A., Toth, A. T. and Koroshegyi, D. (2017) "The export competitiveness of global cocoa traders", Agris On-line Papers in Economics and Informatics, Vol. 9, No. 3, pp. 27-37. ISSN 18041930. DOI 10.7160/aol.2017.090303.

[23] Joas, H. (1996) "The Creativity of Action", Blackwell Publishers Ltd, Oxford OX4 IJF, UK. ISBN-13: 978-0226400440, ISBN-10: 0226400441.

[24] Kamath, S., Agrawal, J. and Chase, K. (2012) "Explaining geographic cluster success - The GEMS model", American Journal of Economics and Sociology, Vol. 71, No. 1, pp. 184-214. DOI 10.1111/j.1536-7150.2011.00819.x. 
[25] Liu, X. and Revell, B. (2009) "Competitiveness change in China's Quality Vegetable exports Post WTO”, Journal of Chinese Economic and Foreign Trade Studies, Vol. 2, pp. 86-99. ISSN 1754-4408. DOI 10.1108/17544400910966068.

[26] Porter, M. E. (1981)“ The Contributions of Industrial Organization To Strategic Management," Academy of Management Review, Vol. 6, No. 4, pp. 609-620. ISSN 0363-7425. DOI 10.5465/amr.1981.4285706.

[27] Qin, X. and Pastory, D. (2012) "Comparative Analysis of Commercial Banks Liquidity Position: The Case of Tanzania", International Journal of Business and Management, Vol. 7, No. 10, pp. 134-141. ISSN 1833-3850. DOI 10.5539/ijbm.v7n10p134.

[28] Qineti,A., Rajcaniova, M. and Matejkova, E. (2009) “The competitiveness and comparative advantage of the Slovak and the EU agri-food trade with Russia and Ukraine", Agricultural Economics, Vol. 55, No. 8, pp. 375-383. ISSN 0139570X. DOI 10.17221/42/2009-agricecon.

[29] Romer, P. M. (1990) "Endogenous technological change”, Journal of Political Economy, Vol. 98, No. 5, pp. S71-S102. ISSN 1537534X. DOI 10.1086/261725.

[30] Sarker, R. and Ratnasena, S. (2014) "Revealed Comparative Advantage and Half-a-Century Competitiveness of Canadian Agriculture: A Case Study of Wheat, Beef, and Pork Sectors", Canadian Journal of Agricultural Economic, Vol. 62, No. 4. pp. 519-544. ISSN 18041930. DOI $10.1111 /$ cjag. 12057 .

[31] Shoufeng, C., Feng, L. and Jiao, Z. (2011) "Export competitiveness of Agri-products between China and Central Asian Countries: A comparative analysis", Canadian Social Science, Vol. 7, No. 5, pp. 129-134. ISSN 1712-8056.

[32] Snowdon, B. and Stonehouse, G. (2006) "Commentary: Competitiveness in a globalized world: Michael Porter on the microeconomic foundations of the competitiveness of nations, regions, and firms", Journal of International Business Studies, Vol. 37, No. 2, pp. 163-175. ISSN 00472506. DOI 10.1057/palgrave.jibs.8400190.

[33] Svatos, M., Smutka, L. and Miffek, O. (2018) "Competitiveness of agrarian trade of EU-15 countries in comparison with new EU member states", Agricultural Economics (Zemédělská ekonomika), Vol. 56, No. 12, pp. 569-582. ISSN 0139570X. DOI 10.17221/129/2010-agricecon.

[34] Vollrath, T. L. (1991) "A Theoretical Evaluation of Alternative Trade Intensity Measures of Revealed Comparative Advantage”, Weltwirtschaftlics Archiv, Vol. 127, pp. 265-280. ISSN 00432636. DOI 10.1007/BF02707986.

[35] Winoto, J. and Siregar, H. (2008) "Agriculture Development in Indonesia: Current Problem, Issues, and Policies after the onset of the Asian Financial Crisis, the Indonesian economy has", Analisis Kebijakan Pertanian, Vol. 6, No. 1, pp. 11-36. ISSN 2549-7278.

[36] Zaghini, A. (2003) “Trade advantages and specialization dynamics in acceding countries", European Central Bank: Working paper series, No. 249, p. 52 . E-ISSN 1725-2806, ISSN 1561-0810.

[37] Zhang, Y., Li, H., Li, Y. and Zhou, L.-A. (2010) "FDI Spillovers in an Emerging Market: The role of Foreign Firms' Country Origin Diversity and Domestic Firms Absorptive Capacity", Strategic Management Journal, Vol. 31, pp. 969-989. ISSN 01432095. DOI 10.1002/smj.856. 


\section{Appendix}

Dependent Variable: Y?

Method: Pooled Least Squares

Date: 03/01/20 Time: 07:50

Sample: 20102017

Included observations: 8

Cross-sections included: 5

Total pool (balanced) observations: 40

\begin{tabular}{ccccc}
\hline Variable & Coefficient & Std. Error & t-Statistic & Prob. \\
\hline C & -19.81574 & 7.433521 & -2.665728 & 0.0145 \\
X1? & $-2.97 \mathrm{E}-06$ & $3.51 \mathrm{E}-06$ & -0.845785 & 0.4072 \\
X2? & $8.86 \mathrm{E}-11$ & $5.00 \mathrm{E}-11$ & 1.770134 & 0.0912 \\
X3? & 0.066698 & 0.032744 & 2.036962 & 0.0545 \\
X4? & 0.00074 & 0.001574 & 0.470212 & 0.6430 \\
X5? & $3.74 \mathrm{E}-06$ & $4.18 \mathrm{E}-06$ & 0.893487 & 0.3817 \\
X6? & -0.704846 & 0.379341 & -1.85808 & 0.0772 \\
X7? & $1.62 \mathrm{E}-05$ & $8.27 \mathrm{E}-06$ & & 1.955168
\end{tabular}

Fixed Effects (Cross)

$\begin{array}{rr}\text { _SINGAPORE--C } & -6.148406 \\ \text { _MALAYSIA--C } & -1.776322 \\ \text { - THAILAND--C } & -8.352781 \\ \text { - VIETNAM--C } & 5.984002 \\ \text { _PHILIPINE--C } & 10.29351\end{array}$

Fixed Effects (Period)

$\begin{array}{ll}2010--C & 4.574004 \\ 2011--C & 2.075178 \\ 2012--C & 0.922327 \\ 2013--C & -0.906194 \\ 2014--C & -1.292504 \\ 2015--C & -0.933952 \\ 2016--C & -1.707206 \\ 2017--C & -2.731654\end{array}$

Effects Specification

Cross-section fixed (dummy variables)

The period fixed (dummy variables)

\begin{tabular}{lclc}
\hline R-squared & 0.984398 & Mean dependent var & -4.800534 \\
Adjusted R-squared & 0.971026 & S.D. dependent var & 7.062737 \\
S.E. of regression & 1.202208 & Akaike info criterion & 3.511839 \\
Sum squared residual & 30.35138 & Schwarz criterion & 4.314057 \\
Log-likelihood & -51.23679 & Hannan-Quinn criteria. & 3.801896 \\
F-statistic & 73.61224 & Durbin-Watson stat & 1.866768 \\
Prob(F-statistic) & 0.00000 & &
\end{tabular}

